\title{
Private finance integration to affordable housing production: a comparison between Copenhagen and Istanbul
}

\author{
Suheyla Turk ${ }^{1}$ iD \\ Received: 7 December 2017 / Accepted: 15 December 2018 \\ (C) The Author(s) 2019
}

\begin{abstract}
This study analyzes transformations in institutions of affordable housing production connected to neoliberalization, which have impacted affordability rates and income gaps in Copenhagen and Istanbul. Also, different types of affordable housing began to develop, such as modular housing of Almenbolig+ in Copenhagen and housing for very lowincome people in Istanbul. Increased affordability rates are the results of the transformations of welfare state-based practices to market-based approaches. The aim of this paper is to analyze and compare how affordable housing institutions have transformed from being financed through public funds to private funding sources since the periods of financial crisis in 2001 and 2008 in a Western and non-Western country. Using the concept of neoliberal localization, this comparative case study employs variation finding tool to analyze the transformations under three causal mechanisms. The first mechanism is state withdrawal of providing finance to affordable housing production; second, collaboration with private sector for financing affordable housing while increasing authority of municipalities. The third mechanism is restructuring institutions to open a base for public-private partnerships. Primary data was provided from interviews, while secondary data was gathered from planning policies, legislations, OECD and country statistics. The outcome of this study reveals information about changes in affordable housing institutions and neoliberal effects on affordable housing production due to contributions of local governments contingent on requirements of private funding.
\end{abstract}

Keywords Affordable housing · Public-private partnerships $\cdot$ Institutional transformations $\cdot$ Neoliberalization $\cdot$ Almenbolig $+\cdot$ Copenhagen $\cdot$ Istanbul

The datasets generated during and/or analyzed during the current study are available in the suheyla turk's Quick Files repository https://osf.io/p3ntu/.

Suheyla Turk

suheyla.turk@keg.lu.se

1 Department of Human Geography, Lund University, Geocentrum I, Sölvegatan 10, 22362 Lund, Sweden 


\section{Introduction}

Since the 1980s, production of affordable housing slowed globally, while land and housing prices increased considerably (Rhodes and Mullins 2009). States have contributed to direct support of individual well-being, employment, health, and education in many countries. However, Affordable Housing (AH) production declined in many European countries between 1990 and 2016, see Fig. 1. Reductions in production subsidies for AH given by states was one result of state withdrawal from direct "welfare provision", according to Rhodes and Mullins (2009, p. 112) a first step of embedding private finance in AH production.

The retrenchments in welfare expenses took place not only in Western countries (Morel et al. 2012; Palier and Hay 2017). Also, private finance integration observed with promotions for home ownership and mortgage lending, housing construction booms, and local Public-Private Partnerships (PPPs), which were enabled by neoliberal policies of housing.

As explained by Fox-Rogers and Murphy (2015, p. 42):

Associated with the neoliberalization of planning is the growing reliance of local government on the private sector marked by the emergence of Public Private Partnerships (PPPs), quangos, and other forms of collaborative governance arrangements between the public and private sphere.

Mayer and Kunkel (2012, p. 18) emphasized that neoliberalization in both Western and non- Western countries have become "destructive" and created "severe social polarization" on the local level. Severe social polarization has been observed with growing income gaps between the richest and poorest in Western and non-Western countries since the 1980s (Mayer and Kunkel 2012). Reducing state support to inhabit or subsidize low income people by deregulation of affordable housing policies have increased spatial inequalities. The issue of deregulation and inequalities are intertwined making it hard to decide which led to the other in "the toleration of rising inequalities or the deregulation that allowed inequalities to rise" (Dorling 2014, p. 126). In other words, the tendency of reducing regulation in housing markets in countries, such as reducing the state support to make Affordable Housing $(\mathrm{AH})$ become accessible is in parallel with increasing gap between the poorest and richest (Dorling 2014).

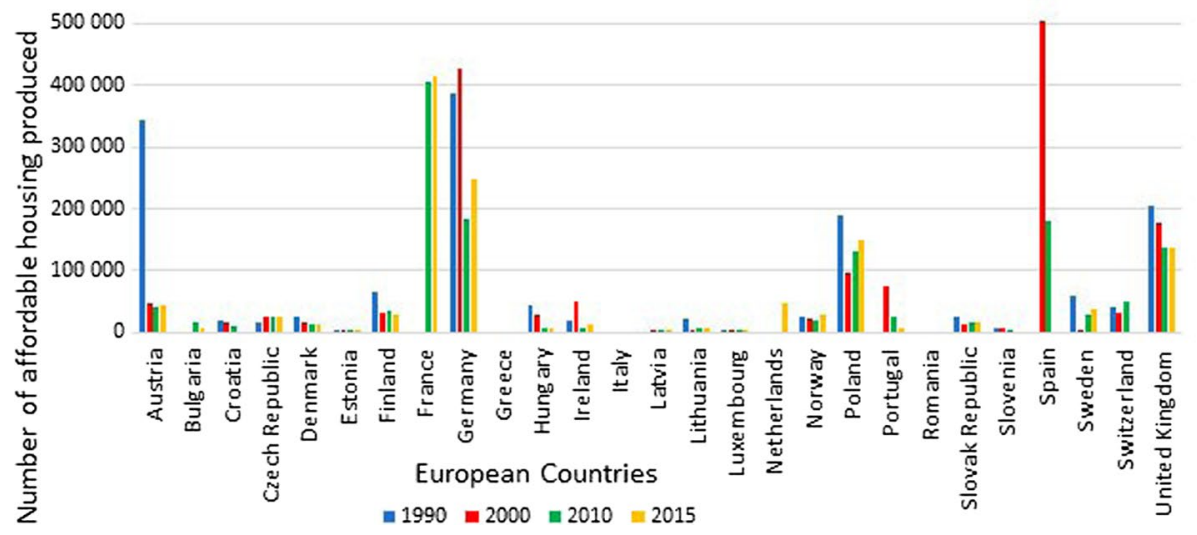

Fig. 1 Affordable housing stock of European countries in 1990 and construction in 2000, 2010 and 2015 (OECD 2016) 


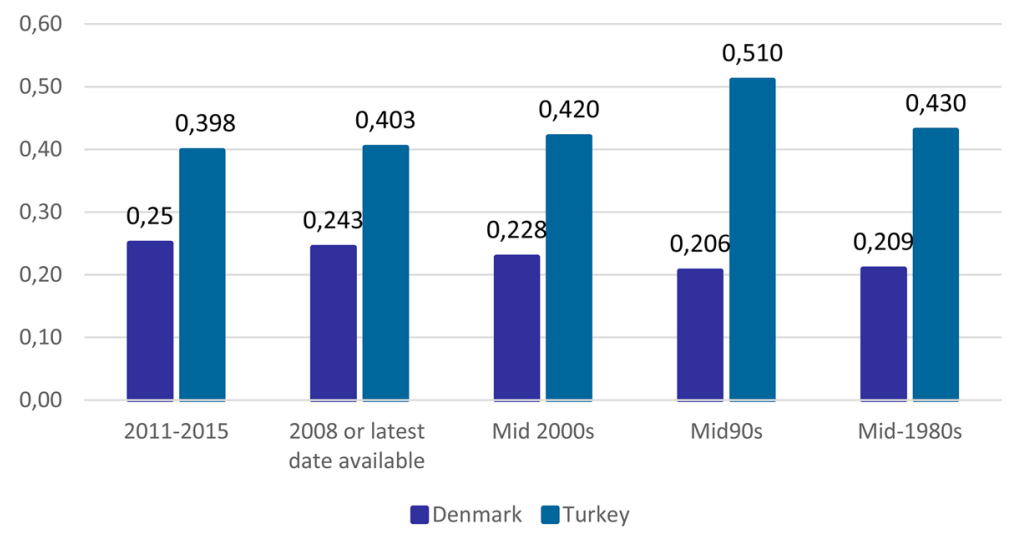

Fig. 2 Changes in gini-coefficients of income inequality from mid-1980 to 2015 in Denmark and Turkey (OECD 2011, 2018)

Financial crises in countries are catalysts of change in planning policies to embed neoliberal projects that impose free market rules and lead to increase in income inequalities. Western states respond to financial crises by imposing strict control of public institutions that make markets more flexible to allow entry of private sector (Mayer and Kunkel 2012). Non-Western states have used strategies of Western states to promote private sector by policy transfers (Mayer and Kunkel 2012). For example, IMF provided financial support on the condition of state promotion of PPPs in Turkey and Argentina in financial crisis of 2001, and financial crisis in Mexico of 2007 (Bugra and Candas 2011; Marois 2011; Önis 2006). The common outcome of the process in many countries is the empowerment of private sector, even in $\mathrm{AH}$ production. This research answers the question pertaining to how institutions of $\mathrm{AH}$ production is restructured to open a base for PPPs after the integration of private finance in two selected cases.

In this study, cases selected from a Western and a non-Western Country involve two different welfare systems keeping one of the lowest (Denmark) income gaps by 0.25 and the highest (Turkey) by 0.398 in 2015 (OECD 2018). AH production as a type of welfare provision in Denmark and Turkey is assumed to act as an obstacle against growing income inequalities. An increase in income inequalities emerged after a gradual privatization process in the mid-80s and became remarkable in the 90s in Turkey (Önis 2011). Even though Turkey has shown a downward trend in income inequality since the mid-2000s, poverty rates are still high (OECD 2011, 2018). Denmark has shown a remarkable increase in income inequality between mid-90s and 2000s after Copenhagen city was almost bankrupt (OECD 2011, 2018). Income inequalities occurring in both countries are shown in Fig. 2.

However, by observing the case studies in this paper, private finance integration has changed AH production in Copenhagen and Istanbul in three ways. First, social expenditure for low income people differed in time. Second, the number and types of AH changed and local Public Private Partnerships (PPP) were used. Third, the affordability rate has become more than $30 \%$ due to increases in land prices, construction costs, rents and monthly installments of $\mathrm{AH}$. The term $\mathrm{AH}$ is used in this study to explain housing that has been subsidized publicly to meet the needs of a relative community (De Kam et al. 2008). In this study the relative community consists of low-income people and $\mathrm{AH}$ provided by state or non-profit institutions (Marsh and Mullins 1998). AH production institutions are defined in this study as institutions responsible for physical production and provision of 
AH for low income people. AH production institutions are also responsible to specific laws and regulations. Cooperative housing production is not a part of this study.

Neoliberal effects on AH studied considering state support for public housing privatization, encouraging home ownership by mortgage and low production levels of new $\mathrm{AH}$ (Dodson 2006; Hananel 2014; Kadi and Musterd 2015). Moreover, Priemus and Boelhouwer (1999) analyzed institutional structure of $\mathrm{AH}$ in seven countries in Europe including Denmark in terms of government subsidies, macro housing quotas, financial sources of new production and renovation, governmental guarantees of interest rates and mortgage loan borrowing. In Denmark, the mortgage period for AH construction loans was changed from 35.5 to 50.5 years, which led to reduction in amount of annual installment payments in 1990 (Priemus and Boelhouwer 1999). Additionally, subsidies were provided to lower interest of loans (Priemus and Boelhouwer 1999).

This study builds on recent findings related to the work of Priemus and Boelhouwer (1999) and adds information about the changing roles of state, municipalities and private institutions to finance $\mathrm{AH}$ production until 2016. The aim of this paper is to analyze and compare how affordable housing institutions have transformed from being financed through public funds to private funding sources since the periods of financial crisis in 2001 and 2008 in a Western and non-Western country. Even though Denmark and Turkey have different types of welfare provision, tax return systems and different housing market types, institutions of AH production were transformed by similar neoliberal mechanisms.

Transformations emerged with financial crisis in 2001 when financial sources of $\mathrm{AH}$ production institutions changed after cutting state budget in Turkey. In Denmark, a private funding institution has started to guarantee majority of mortgage loans for NHAs on behalf of state in 2002. One outcome of this study shows how different types of AH production, Almenbolig+ in Copenhagen and AH for very low-income people in Istanbul, began to develop. During institutional transformations, three mechanisms consisting of events were observed. A historical order of events in each case are analyzed considering neoliberal localization concept to explain institutional transformations.

The first mechanism is state withdrawal of providing finance to AH production; second, collaboration with private sector for financing AH while increasing authority of municipalities. The third mechanism is restructuring institutions to open a base for PPPs. An additional unexpected fourth mechanism, different than neoliberal localization concept, emerged during this study. State came back to the role of welfare provision for financing AH production for very low-income residents in both cases. One of the Turkish ministries subsidizes AH construction to keep rents lower, while Danish state purchases bonds and provides loans from private mortgage banks.

\section{Background}

There are four essential differences contingently related to changes in institutions of affordable housing production in the selected cases. These are welfare provision and tax returns, housing market and tenure type; the share of private mortgage loans for home ownership and GDP rates and relative income poverty. First, in Denmark, 20\% of income taxes are transferred to local governments to provide welfare to citizens (Goul Andersen 2011). In Turkey, state is the only entity responsible for welfare provision and tax returns. Second, Denmark has an integrated housing market in which the state controls rental amounts for both private and public housing. In Turkey, there is a dual 


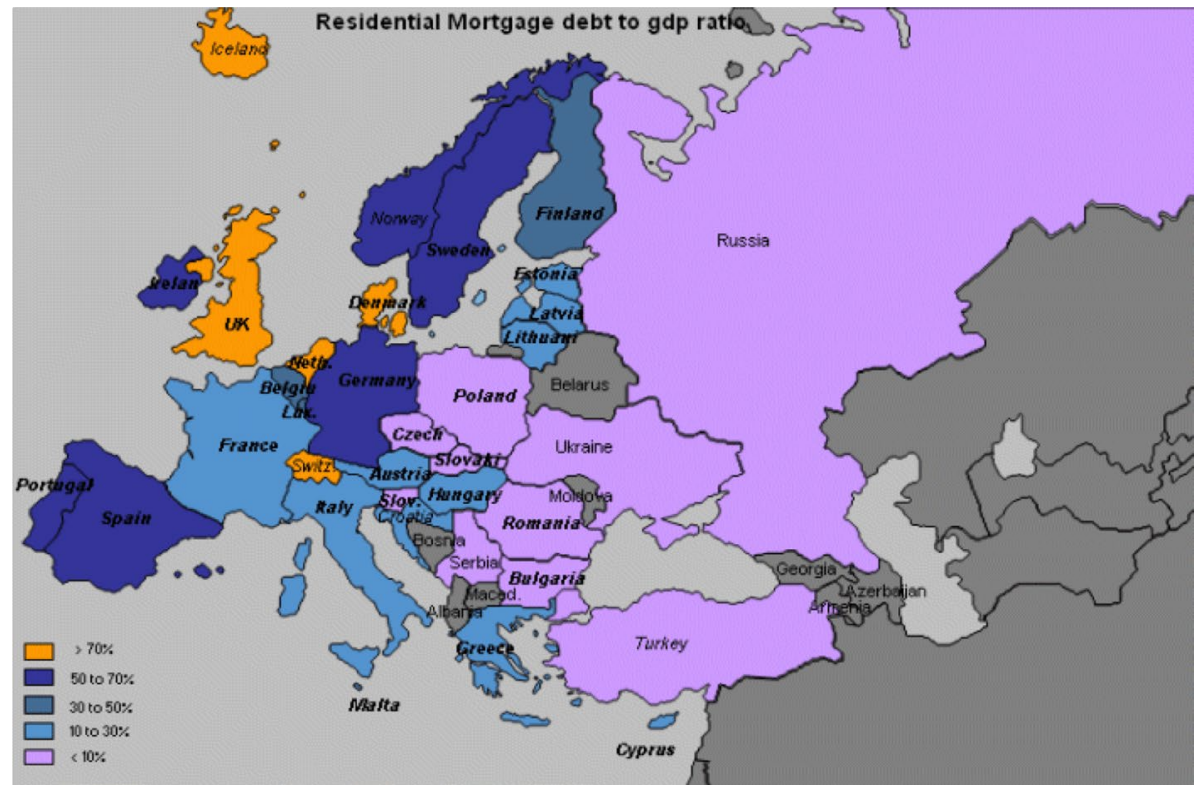

Fig. 3 Residential mortgage debt to GDP ratio (Tsenkova 2008, p. 25)

housing market, which does not modify markets. Denmark has a home ownership rate of 50.6\%, with an affordable rental housing rate of 22\% (Scanlon et al. 2015). Turkey has dual housing market with a home ownership rate of $68 \%$, while affordable owneroccupied housing rate was approximately 10\% in 2013 (Coskun 2015). Third, mortgage loan usage rates to purchase houses are different. The rate of residential mortgage debt to GDP ratio is higher in Denmark than in Turkey. The rate is $65 \%$ in Denmark, but $5 \%$ in Turkey (European Commision 2015, EUROSTAT 2016), shown in Fig. 3 (Tsenkova 2008, p. 25). Reluctance to use of mortgage loans is due to TOKI's low interest rate was $4 \%$ for $\mathrm{AH}$ residents making housing purchases from TOKI preferable (TOKI 2011). Since private banks offered mortgage loans with interest rates between 10 and $14 \%$ in 2011 (TMB 2018). Fourth, Turkey had the second highest relative income poverty by $17.3 \%$ among OECD countries. On the contrary to Turkey, Denmark had the lowest income poverty by 5.5 among OECD countries in 2015 (OECD 2017).

Similar policy changes in institutional transformations such as to promote private sector and local level PPPs for AH production are observed. The first local PPPs for $\mathrm{AH}$ productions were established in Copenhagen for the Emaljehaven project in 2008 and in Istanbul for the Sulukule project in 2009. Brenner and Theodore (2002, p. 349) describe "neoliberal localization" process; first limiting public finance for local governments while increasing their authorities and second encouraging adoption of private sector or revenue-sharing methods. A final aspect of this restructuring of institutions is to open a base for PPPs to provide local government services (Brenner and Theodore 2002). 


\section{Method}

This study compares the process of $\mathrm{AH}$ institutional transformations and reveals the results considering affordability rates by analyzing the share of rent amounts, or monthly installments of $\mathrm{AH}$ units to residential equalized incomes of low-income households in Copenhagen and Istanbul. To compare processes of institutional transformations, successive events are considered during the analysis of institutional transformation that stem from neoliberal influences. The institutional transformations emerged with causeeffect relationships based on housing and planning policies.

The two cases have many variables, referred to as differences, affected by one common mechanism being the integration of private finance in changing institutions in $\mathrm{AH}$ production, of which PPP involvement is extracted as one common outcome. This study uses a methodological tool called variation finding comparison to work with systematic differences between cases (Pickvance 2001). Differences can be analyzed under the common feature, a dimension or a concept, called "conceptual equivalence" (Pickvance 2001, p. 24). According to Pickvance (2001) empirical differences need to be considered to design a research study (Pickvance 2001). Mahoney (2000) explains institutional change as a concept of self-reinforcing sequences. According to Mahoney (2000), an unexpected initial event promotes changes in institutions, which is followed by successive events that continue to change the structure of an institution. These successive events generate causal mechanisms that influence the institution to work differently than past actions (Mahoney 2000).

In this paper, an initial event starts with budget cuts in $\mathrm{AH}$ production institutions; following events are observed in integration of private finance. The initial event and following events, which create causal mechanisms, are analyzed by a literature review of laws in housing and planning policies. Three causal mechanisms observed based on neoliberal localization concept. The first to limit public finance while increasing authorities of local governments; the second is to encourage private sector or revenue-sharing methods; the third is to restructure institutions to open a base for PPPs (Brenner and Theodore 2002).

\subsection{Data}

The data for this research consists of primary data for analysis of legal documents and interviews. Documents gathered for the Denmark and Turkish cases include municipal plans; laws about rent subsidies to citizens; AH laws, regulations and statistical documents from OECD, see Table 1. The number of AH units produced in Istanbul were obtained from the website of TOKI while Copenhagen Municipality's supplementary planning documents include information about the number of produced AH units. Turkish Statistics Institutute (Turk Istatistik Kurumu, TUIK) documents for Istanbul were used to obtain equalized household income in 2016; the source for Copenhagen was Status på København 2018 to evaluate housing affordability rates.

A rent analysis to calculate the affordability rates in Copenhagen were conducted on 16th of June and in 24th July in 2018. The data for the rent analysis was drawn from the $\mathrm{KAB}$ website, a nonprofit housing association, which owns and manages AH mainly located in Copenhagen (Kab-selvbetjening 2018a). Interviews were conducted in Denmark 


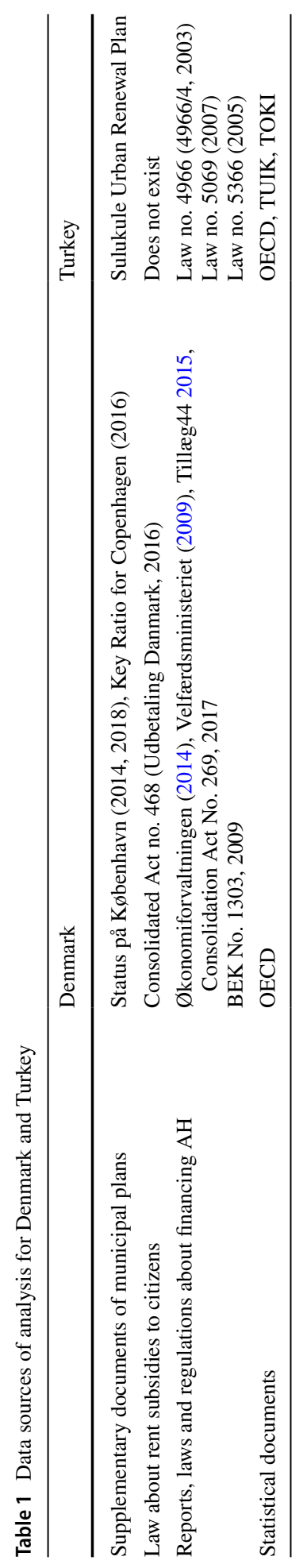




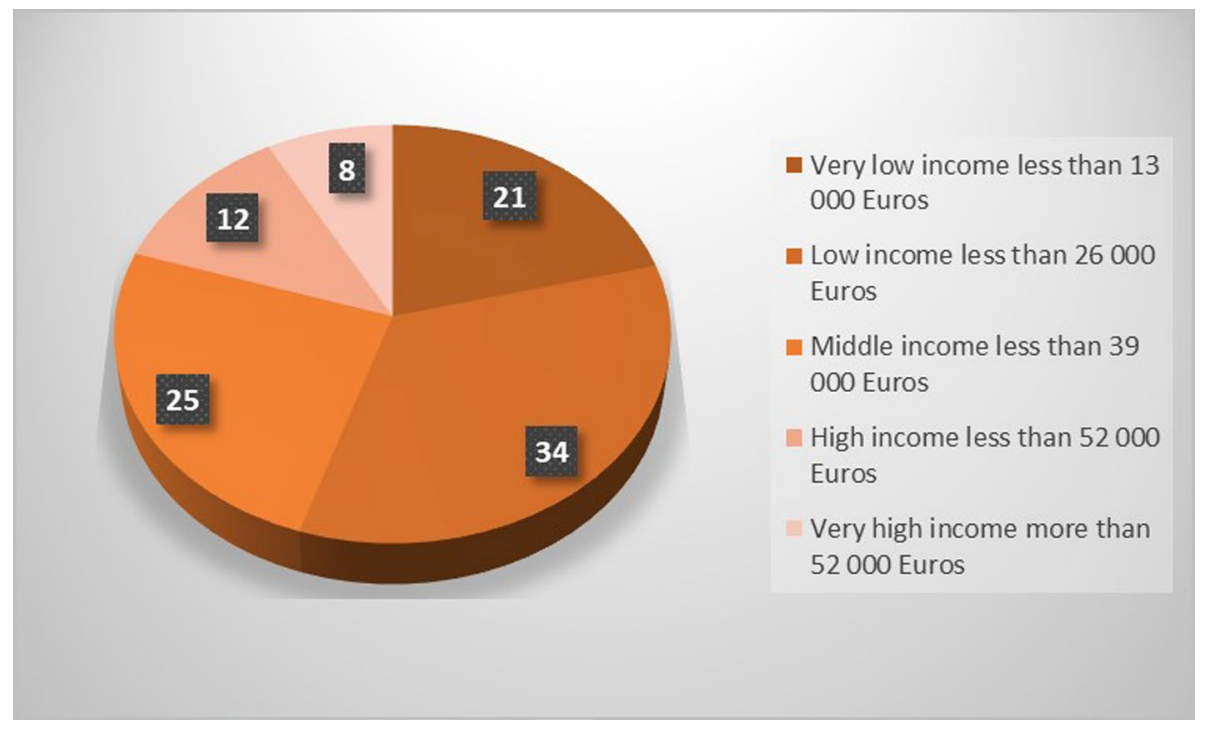

Fig. 4 Income distribution in Copenhagen in 2016 (Kommune 2018, p. 21)

with a NHA and Copenhagen Municipality. Interviews were also done with representatives of TOKI and local municipality in Istanbul.

\subsection{Household income in Copenhagen and Istanbul}

The population of the metropolitan area of Copenhagen was 580.300 in 2015 (Kommune 2016). The annual income distribution in 2016 reflected that $21 \%$ of the population consists of very low income households earning less than 13.000 Euros $^{1}$ (Kommune 2018, p. 21). $34 \%$ of the population earned less than 26.000 Euros, while $25 \%$ of population earned less than 39,000 Euros as middle income holders, as shown in Fig. 4 below (Kommune 2018 , p. 21). On the other hand, $18 \%$ of the population had high incomes earning less than 52,000 Euros, while very high income households had more than 53,000 Euros (Kommune 2018, p. 21).

Istanbul had a population of 14 million in 2015 (Eurostat 2016) and the distribution of annual equivalized household disposable income is ordered by five quintiles by TUIK between 2006 and 2016 for Istanbul (TUIK 2017). A median of very low-income households, consisting of $6.7 \%$ of population, was 2712 Euros per year while $10.3 \%$ of population was low income households earned 4043 Euros in 2016 (TUIK 2017). 14.1\% of households had 5435 Euros who were middle income, 20\% of households had 7533 Euros consisting of high income and $49 \%$ of households had very high income earning 14,417 Euros annually (TUIK 2017).

\footnotetext{
1 Euro conversion from DKK and TL was done considering the data of European Central Bank Euro system (EcbEurope, 2016). In 2016, 1 TL was equal to 0,3 Euro, while 1 DKK was equal to 0,13 Euros.
} 


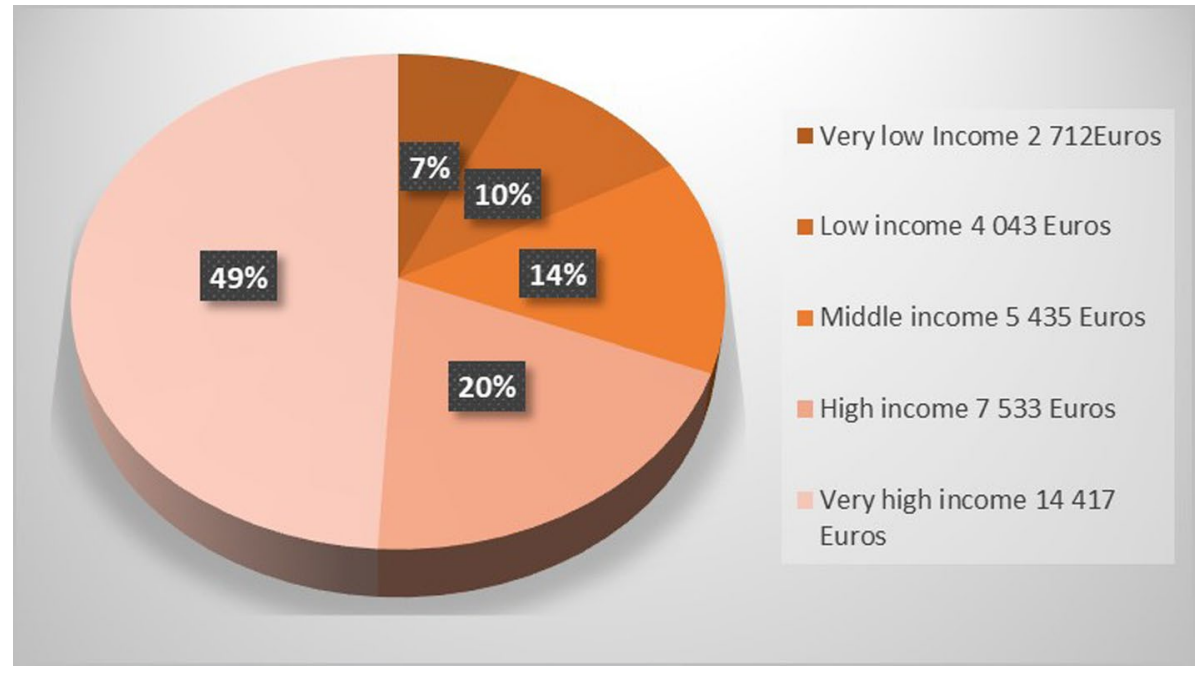

Fig. 5 Income distribution in Istanbul in 2016 (TUIK 2017)

According to Official Gazette of Turkey, a worker receiving social security had a minimum monthly salary of approximately 494 Euros, 5929 Euros annually, in 2016 (OfficialGazette 2015; URL-1 2016). According to TUIK, statistics shown in Fig. 5 below, this example of a worker's wages is claimed to represent a middle-income household in 2016. The living expenses of people at risk of poverty was collaboratively defined by workers' unions to be 525 Euros monthly and 6300 Euros annually (URL-1 2016).

According to given data, people earning low, very low and middle incomes in Istanbul, consisting of $31 \%$ of the population, were at risk of poverty in 2016, in contrast to the Official Gazette of Turkey. An umbrella organization of Turkish Chamber of Engineers, Architects and City Planners announced the minimum salary of people who have a university education, as being 990 Euros monthly and 11,880 Euros annually, which was high income in 2016 according to TUIK (TUIK 2016, 2017; TMMOB 2015).

\section{Analysis of institutional transformations of AH production}

This section provides information about the relationships between institutional changes and causal mechanisms in Copenhagen and Istanbul. In Turkey's financial crisis of 2001, the national government began to support urban renewal practices with revenue-sharing methods to promote Istanbul's global competitiveness (Karaman 2008). International Monetary Fund gave funds on the condition that Istanbul is planned to become a global city (Karaman 2008). In Copenhagen, the adoption of European Union policies with strengthened spatial planning since the 1990s, when Copenhagen Municipality was almost bankrupt. European Union policies have been based on diversity, which has bolstered private and localized development by deregulation policies (Galland 2014). Therefore, urban planning changed direction from the 
Table 2 Financial support to AH production (Transport 2018; Velfærdsministeriet 2009, p. 13)

\begin{tabular}{llllllll}
\hline Year & $\begin{array}{l}\text { Tenants } \\
\text { deposit }\end{array}$ & $\begin{array}{l}\text { State contri- } \\
\text { bution }\end{array}$ & $\begin{array}{l}\text { Municipal } \\
\text { contribution }\end{array}$ & LBF & $\begin{array}{l}\text { Private } \\
\text { mortgage }\end{array}$ & \multicolumn{2}{l}{\begin{tabular}{l} 
Mortgage guarantee \\
\cline { 5 - 7 }
\end{tabular}} \\
\hline 1975 & 3 & 10 & 5 & 8 & 74 & 100 & 0 \\
1989 & 2 & 4 & 4 & 0 & 94 & 100 & 0 \\
1990 & 2 & 0 & 4 & 0 & 94 & 100 & 0 \\
2002 & 2 & 0 & 7 & 0 & 91 & $29-47$ & $71-53$ \\
2007 & 2 & 0 & 14 & 0 & 84 & 75 & 25 \\
2012 & 2 & 0 & 7 & 0 & 91 & 75 & 25 \\
2016 & 2 & 0 & 10 & 0 & 88 & 75 & 25 \\
\hline
\end{tabular}

stance of equality to liberal by adapting goals to promote privatized local development to become a global city (Galland 2012, 2014). AH became involved in a series four events, creating financial contexts for the shaping of causal mechanisms of institutional changes in $\mathrm{AH}$ production.

\subsection{Private finance integration in $\mathrm{AH}$ production and policy changes in Copenhagen}

In Denmark, the production of $\mathrm{AH}$ is financed by tenant's deposits of $2 \%$, municipal basic capital between 7 to $14 \%$ and credit institution loans with state guarantee from 84 to $94 \%$ (Velfærdsministeriet 2009). State has never directly financed affordable housing construction (Turner 1999). Instead, the Ministry of Housing provided mortgage loans from private banks on behalf of state and payback was guaranteed by state in 1975 (Turner 1999). The amount of state provision of mortgage loans changed from $10 \%$ in 1975 , reduced to $4 \%$ in 1989 , then were completely abolished in 1990, Copenhagen Municipality was almost bankrupt, see Table 2 (Velfærdsministeriet 2009, p. 83).

First, in 2002, 100\% municipal guarantees for mortgage lending of nonprofit housing associations (NHAs) were lowered (Jensen 2013). Before 2002, municipalities in Denmark were guaranteeing mortgage loans $100 \%$ for NHAs. The payback period for the borrowed loans was up to 50 years free of charge until 2000 (Priemus and Boelhouwer 1999; Velfærdsministeriet 2009). Mortgage loans were given by private mortgage and commercial banks (Boligkontoret 2007) and interest rates were guaranteed by state to be kept low (Tsenkova and Vestergaard 2011). NHAs purchase mortgages by paying for interest rates and bank charges, which was established as equal to $3.4 \%$ of building costs produced after 1999 (Scanlon et al. 2015). Mortgage repayment fees became more than the amount borrowed and led state to make profit from selling mortgages, even though the state pays the mortgage costs to private banks (Scanlon et al. 2015). In addition to these changes mentioned, increased land prices led to high $\mathrm{AH}$ construction costs and higher rent requirements for AH produced after 1999.

In 2002, the maximum payback period for municipality provided guarantees for mortgage loans via LBF reduced to 30 years (Velfærdsministeriet 2009, p. 69). Financing rules of $\mathrm{AH}$ were changed and stimulated NHAs to produce $\mathrm{AH}$ with higher rents to reimburse deficits in later years (Jensen 2013). A private funding institution, 
Table 3 Financial support to AH production (Kab-selvbetjening, 2018a, b, c)

\begin{tabular}{lll}
\hline Type of housing in 2018 & $\begin{array}{l}\text { Rents per square meter Sund- } \\
\text { bygård, Copenhagen (South) }\end{array}$ & $\begin{array}{l}\text { Rents per square meter } \\
\text { Grøndalsvænge, Copenhagen } \\
\text { (Northwest) }\end{array}$ \\
\hline Almeneboliger+ & 14 Euros & 13 Euros \\
AH units produced after 2005 & 13 Euros & 16 Euros \\
$\begin{array}{l}\text { AH units produced between 1941 } \\
\text { and 1959 }\end{array}$ & 9 Euros & 7 Euros \\
\hline
\end{tabular}

Landsbyggefonden started to guarantee 53-71\% of mortgage loans for non-profit housing associations on behalf of municipalities (Velfærdsministeriet 2009, p. 83). Landsbyggefonden is an independent organization established based on a law in 1967 by nonprofit housing associations (LBF 2015). Associations give 50\% of their annual income as paybacks of borrowed mortgage loans to Landsbyggefonden (Tsenkova and Vestergaard 2011). Also, 7\% of interest free loans were given from municipalities via Landsbyggefonden, as shown in Table 3 above until 2007 (Velfærdsministeriet 2009, p. 83).

Second, the municipality of Copenhagen provided guaranteed mortgage loans that increased to $75 \%$ of a property purchase price in 2007 (Velfærdsministeriet 2009, p. 71). The support of Landsbyggefonden to guarantee mortgage loans for non-profit housing associations on behalf of state was reduced to $25 \%$, while municipal guarantee increased to $75 \%$ by Act No. 547, see Table 3 above (Transport 2018, p. 13). Meanwhile, municipal contribution previously provided interest-free loans that increased to $14 \%$ in 2007 via LBF, reduced to $7 \%$ in 2012, and increased to $10 \%$ in 2016 (Finansministeriet 2015, p. 35; Velfærdsministeriet 2009, p. 71). Then, public housing act of 2013 gave responsibility to Landsbyggefonden to administer loans for NHAs without interest rates until 2018 (LBF 2013; LSF135 2013). Landsbyggefonden provided funds between 2015 and 2018 as guaranteed mortgages for new AH construction done by 25\% rule (Transport 2018, p. 13).

Fourth, in 2018 a law came into force consisting of a state-owned system that purchases private bonds to subsidize AH production (LOVN0773 2018; Nationalbanken 2017). To provide loans, the mortgage banks pay a $0.12 \%$ loan fee to the state (Transport 2018; Denmark 2017). Law number 0773 led to an increase in construction expenses of NHAs and may lead to a growth in deposit payments of tenants in future. To sum up, financing AH production became more market oriented due to the commitment of purchasing private bonds and loans.

\subsection{Changing roles of local governments in $\mathrm{AH}$ production and policy changes in Copenhagen}

A dissimulation of the Metropolitan Council of Copenhagen in 1994 streamlined decisionmaking processes by transferring many duties to city and regional councils (Galland 2014). The local planning duties are under the control of Ministry of Environment (Galland 2014). Also, municipalities had responsibility to determine the quantity of new AH stock in 1997 (Kristensen 2002). The public housing act of 1997 gave a role to city council to control the annual budget of NHAs (Galland 2014). Another change in municipal duties occurred in 2007, which included proving youth courses, health care duties, integration of immigrants to community and creation of local business services (Hansen 2007). In addition to 
this, the local income taxation kept independent from municipality to municipality on the condition to transfer large amounts to small budget municipalities state (Sellers and Lidström 2007). These changes allowed municipalities to become self-autonomous in relation to urban planning, local infrastructure, and to be powerful actors in $\mathrm{AH}$ provision (Galland 2014).

In financial crisis period year of 2008, a local PPP for a new type of AH production called Almenbolig+ with tenure mix strategy appeared in Copenhagen. The Emiljhaven project started with the purchase of the Glud and Marstrand foundation and signing an agreement with Søtoftegaard A/S to develop a tenant mixed housing project on land owned by the foundation (Hansen 2007). The tenant mixed neighborhood consisted of $60 \mathrm{AH}$ units provided by a NHA, 42 cooperative and 83 owner-occupied units (Hansen 2007). The prefabricated unit housing project was completed in 2008 (Hansen 2007). Copenhagen City shares a budget to be used for purchasing land in central locations of Copenhagen to produce AH with 25\% rule (Tillæg44 2015).

The public housing law of 2015 legalized with tenure mix with AH production by reserving 25\% of land area (ActNo.221 2015). Three NHAs, KAB, 3B and Domea developed Almenbolig+ houses to be used in tenure mixed projects (Kommun 2014). A first local project by the $25 \%$ rule was implemented in the South port area in Teglholmen, Sydhavnen in Copenhagen that consisted of Almenbolig+ units as AH in 2015. The shared budget of city council (Schouenborg 2015, p. 10) is planned to be used to build $10 \%$ of AH as small houses on purchased land using 25\% rule. Almenbolig+ units are prefabricated (Tillæg44 2015), used by young people having a maximum rent of $€ 430.48$ (Schouenborg 2015 , p. 25). The land was purchased by a partnership of NHAs, private and cooperative housing companies. This tenure mixed project includes 6500 square meters AH units produced by this PPP (Turk 2016). Almenbolig+ houses produced as $10 \%$ of 6500 square meter area, which were one room houses, consists of approximately 30 square meters rented for 430 Euros.

\section{Private finance integration in $\mathrm{AH}$ production and policy changes in Istanbul}

The institutional transformation in AH involved in the Istanbul case through four successive events. First in 2001 the financial sources of institution were abolished, and financial resources of TOKI changed (TOKI 2012). Second, TOKI was given authority to implement profit-oriented projects using a revenue-sharing method by law no. 4966 in 2003 to create its own financial resource and cross-subsidize AH production for low income people (4966/4 2003; Palancioglu and Cete 2014). The revenue-sharing is often used in Istanbul by PPPs to capture a rate of profit, usually between 7 and 20\% (TOKI 2016) from sales of constructed houses in lieu of TOKI's given public land to private companies with bidding (TOKI 2012). The rate of profit was proposed by the private companies, and TOKI awarded contracts to companies that promised the highest rate of profit sharing. TOKI has mainly produced housing for middle- and high-income groups in Istanbul consisting of villas, apartments, residential towers and gated communities to cross subsidize AH (Karaman 2008).

Third, a first historical urban renewal project in Istanbul, started in 2006 by a decision of cabinet of ministers and implementation of law number 5366 (Council 2014). Sulukule urban renewal project was implemented between 2009 and 2012 (Günay et al. 2014). This 
project consisted of a local partnership among municipality, a private company and TOKI, which included selling $20 \mathrm{AH}$ units for low income residents, who were Roma people (Council 2014: URL-2).

Fourth, social expenditure for low income in AH established by a partnership of TOKI, local governments, and the Ministry of Family and Social Policies by funding from the General Directorate of Social Assistance and Solidarity in 2009 (Ministry 2009). AH production was partly financed with funding since 2010 by law number 5793, even though AH unit production was minimal in Istanbul 2010 (TOKI 2016). The amount of funding became 1.7 times more in 2013 than 2010 (Eryıldız 2017).

Law number 5366 in 2005 gave the authority to cabinet of ministers to approve the sites for urban renewal offered by metropolitan municipalities. Metropolitan municipalities were empowered by implementation authority of urban renewal projects in parallel with given authority to TOKI to implement urban renewal only if metropolitan or local municipalities do not intend to do in 2005. TOKI provided finance to municipalities for urban renewal. Implemented urban renewal projects by TOKI often did not include AH units (Turk and Altes 2010b). In 2007, land access for TOKI was either free or at prices below market by law number 5069 (Palancioglu and Cete 2014). The free land acquisition is requested by the Ministry of the Economy on behalf of TOKI and confirmed by the Prime Minister. As a result, AH has usually been built on public land since 2007 (Palancioglu and Cete 2014).

\subsection{Result 1: changes in social expenditure for low income people}

Social expenditures in Denmark include demand side subsidies consisting of cash benefits as rent and housing assistance, technical education, and integration to the job market that has been managed by local governments in Denmark. Cash benefits given by municipalities were reduced according to Consolidation Act no. 468 (UdbetalingDanmark 2016) and LBKnumber269 (2017) and encouraged finding a part time job. Kontanthjælpsloft (2016) document reveals the amount of state benefits for a household that consists of a woman aged 30 with two children and a partner (Kontanthjælpsloft 2016). She received cash assistance in 2017, amounting to 1895 Euros and had rent help amounting to 161 Euros per month for living in AH. In total she had 2056 Euros (Kontanthjælpsloft 2016). If she works part time at least $6 \mathrm{~h}$ a week, she can have more income help, which is 2083 Euros monthly (Kontanthjælpsloft 2016).

In Turkey, the General Directorate of Social Assistance and Solidarity linked to the Ministry of Family and Social Policies by law no 633 in 2011. The institution helps people giving unemployment salaries who do not have health care and pension benefits linked to welfare system (GDSA 2017). Similar to the Copenhagen case free technical courses are given by local governments to improve skills of low-income people for increasing their employability (Bugra and Candas 2011). According to interviews with representatives of TOKI in November 2016 and information on the General Directorate of Social Assistance website (GDSA 2017), funding is provided by state to AH for very low-income people. The Ministry of Family and Social Policies aims to keep the monthly instalments of tenants in AH very low; to achieve this, the required housing costs of construction are paid by the ministry to TOKI (Ministry 2009). This type of AH has not been produced in urban renewal areas in the historical core of Istanbul, where living expenses and real estate prices have been escalating; they are produced in peripheries. 


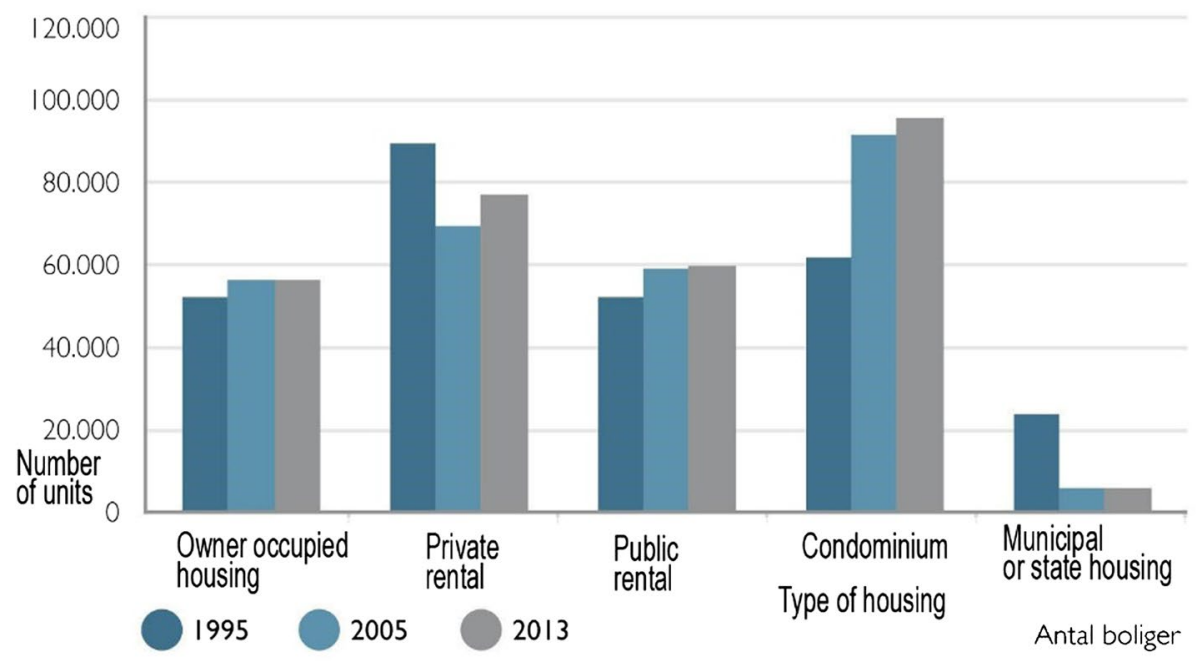

Fig. 6 AH construction in Copenhagen in 1995, 2005 and 2013 (Økonomiforvaltningen 2014, p. 24)

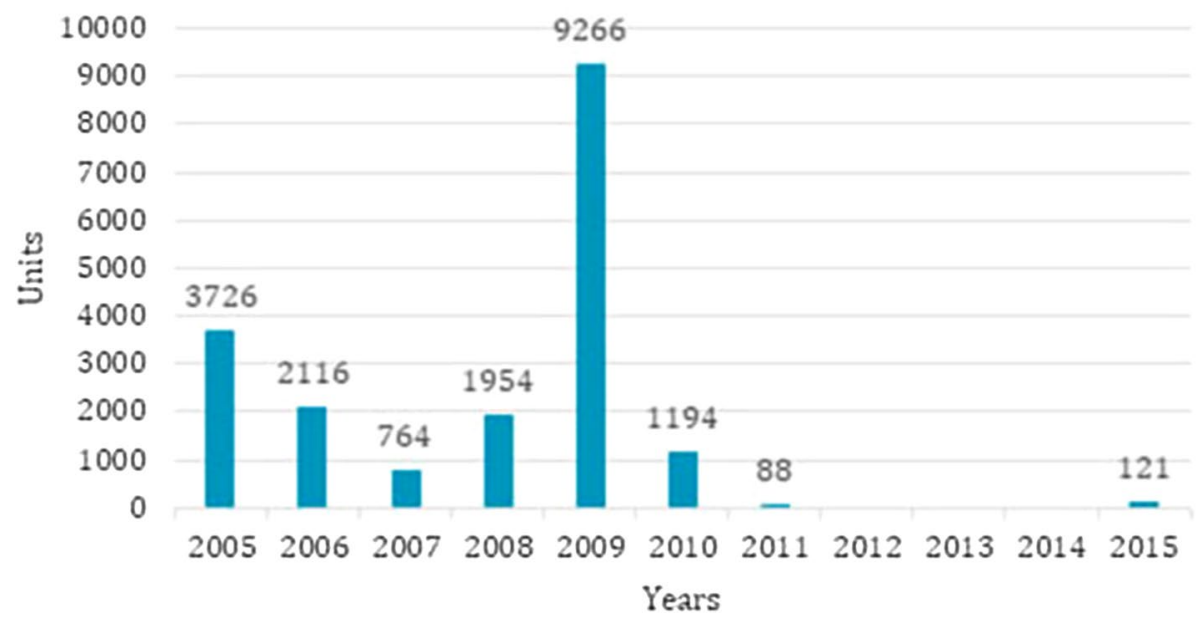

Fig. 7 The number of AH production in Istanbul between 2005 and 2015 (TOKI 2018a)

\subsection{Result 2: changes in the number of AH in Copenhagen and Istanbul}

In Denmark, $\mathrm{AH}$ is produced by NHAs. $68 \%$ of the household living in $\mathrm{AH}$ units are usually single parents with children and 57\% of them are single women (Scanlon et al. 2015). In Copenhagen, contrary to general trend of reducing number of AH production in Europe since the 1990s, there is a growing number of AH units produced by non- profit housing associations in Copenhagen as shown in Fig. 6. However, the rent amounts of AH grew $28 \%$ in the following years of financial crisis.

TOKI's AH is accessible only to those with certain income limits defined by TOKI. In Istanbul, TOKI completed 100\% of 48,683 housing units between 2004 and 2016 (TOKI 


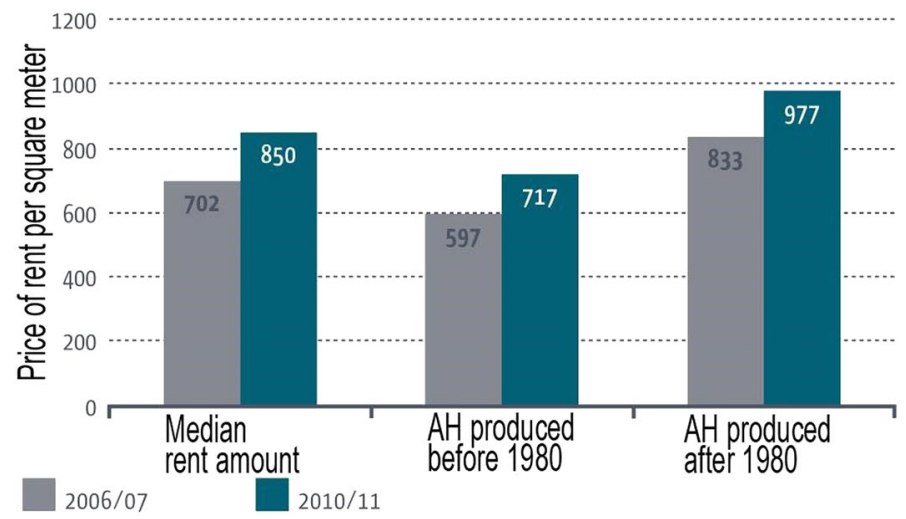

Fig. 8 Changes in rents in AH, which were produced before and after 1980 in Copenhagen in Danish Krone (Kommune 2012, p. 13)

2018a). 35\% of housing units were AH for very low-income households (TOKI 2018a) and sold to very low and low income households for 15 and 25 year long agreements (TOKI 2014). AH were produced in the city's peripheries referred to as Sile, Tuzla, Hadimköy, Tasoluk, Kayabasi (TOKI 2014, pp. 76,90,91) and Silivri (TOKI 2018b). There was an increase in AH production for very low income between 2007 and 2009, which was followed by a sharp decline in following years, shown in Fig. 7.

$23 \%$ of housing for high and very high-income people, all produced by revenue sharing, while $42 \%$ of them for middle-income people. Housing for middle income people were produced by urban renewal (10\%); constructed with (11\%) and without $(21 \%)$ social facilities in Istanbul (TOKI 2018a).

\subsection{Result 3: changes in land prices, AH rents and affordability}

Monthly installments paid by very low income households were a minimum of 90 Euros (300TL) in 2012 in Istanbul (TOKI 2012, p. 25), and increased to 160 Euros (530 TL) (URL-3 2018) in 2016 in Şile (TOKI 2018b), while the installments of Silivri houses are announced as 288 Euros (961 TL) in 2018 (TOKI 2018b). Turk and Altes (2010a) mention that land prices in Istanbul were more than doubled between 2002 and 2008, from 700 to 1900 euros per square meter.

In Copenhagen, an apartment consisting of 85 square meters, constructed before 1980, had a monthly rent of 680 Euros. Figure 8 shows that during 2006 and 2007, AH rents per square meter were between 8 and 10 Euros. During 2010 and 2011, the rent increased by approximately $28 \%$ increase to be 268 Euros, which led to rent became 950 Euros.

\subsubsection{Rent analysis of Almenbolig+ and traditional AH units in Copenhagen}

In 2018, rents of Almenbolig+ houses produced by the PPP in Emiljahaven project in Havnestaden, South Copenhagen are between 1209 and 1716 Euros. The flats consist of three and four rooms with 76 and 108 square meter areas (kab-selvbetjening.dk 2018). The rents per square meter is minimum 14 Euros. Also, traditional AH produced by the same institution before 1960 have 9 Euros, while AH produced in mid-2000 have 13 Euros rents 
per square meter (Kab-selvbetjening 2018c). Almenbolig+ houses are between 100 and 110 square meters including two bedrooms, in Grøndalsvænge of Copenhagen. Houses have monthly rents between 918 and 1250; which are between 10 and 12 Euros per square meter (Kab-selvbetjening 2018b). AH, which produced before 1960 are rented for 7 Euros and those produced after 2005 have 16 Euros rents per square meter in 2018 (Kab-selvbetjening 2018b).

\section{Discussion of affordability rates in Copenhagen and Istanbul}

This study includes calculation of affordability rates for very low-income in $2016.55 \%$ of the population in Copenhagen had low and very low income who earned less than 26880 Euros per year. Contrary to the Copenhagen case, in the Istanbul case, $69 \%$ of population had high and very high income in 2016 (TUIK 2017). Very low-income households earned less than 13000 Euros annually in Copenhagen, while very low-income households earned less than 2712 Euros in Istanbul. It is clear from the population statistics that the reason why $64 \%$ of TOKI's housing production is provided for middle- and high-income people in Istanbul. Since 2006 in Istanbul, the rate of people earning very high income was never lower than $43.5 \%$. Monthly installments of AH for very low-income people in Istanbul was approximately 160 Euros for recipients earning around 226 Euros, which was $70 \%$ of their total income. The official lowest income receiving social security benefits in Istanbul was 494 Euros in 2016 and they paid the same monthly installments to TOKI; therefore, the affordability rate of housing was $32 \%$ for official lowest income holders.

In Copenhagen, a household type is taken into consideration consisting of one working person, one unemployed person who receives welfare cash and rent benefit with two children. A very low income household salary was 1083 Euros, had 1895 Euros cash benefit and 161 Euros rent assistance, which was 3139 Euros in total (Kontanthjælpsloft 2016). If they live in an Almenbolig+ house in Emiljahaven, the required rent is 918 Euros in 2018, at an affordability rate of $29 \%$. If they live in another AH unit, produced in the 1940s, they pay 491 Euros with an affordability rate of $15 \%$ and the rent for units produced in 2013 was 1045 Euros while affordability rate was $33 \%$. To sum up, affordability rates of AH produced in the 1940s is $15 \%$, while for those produced in 2013 is $33 \%$.

\section{Conclusion}

This study analyzed transformations in institutions of $\mathrm{AH}$ production due to private finance integration in Copenhagen and Istanbul, particularly those beginning during financial crisis periods. This research answered how institution of $\mathrm{AH}$ production is restructured to open a base for PPPs after the integration of private finance. This study used neoliberal localization concept consisting of three causal mechanisms.

The first mechanism is to limit public finance while increasing authorities of local governments. AH production was $4-10 \%$ financed by state, $4-5 \%$ by municipalities, $0-8 \%$ by Landsbyggefonden, $2-3 \%$ by tenants' deposits and $74-94 \%$ by private mortgage with $100 \%$ municipal mortgage guarantee until 1990. The mortgage costs are paid to private or mortgage banks. In 1990 when Copenhagen Municipality was experiencing financial crisis, the state stopped financial support to AH production. City councils, which are administered by ministry of environment were authorized to control annual budgets of NHA since 1997. 
Increased numbers of local authorities emerged with receiving the role from municipalities to define the quantity of AH stock in 1997. Municipalities were authorized to provide local business services, technical courses to adults and to determine tax levies in 2007. In 2015, municipalities had the responsibility to request $25 \%$ of land to reserve on land use plans to produce $\mathrm{AH}$. Also, municipalities have right to change the function of the land from industrial or business to residential function, which is applicable by $25 \%$ rule. City council provided a budget in 2015 to purchase land in the city center, where land prices were higher.

The second mechanism is collaboration with private sector for financing $\mathrm{AH}$ such as to encourage the private sector to enable revenue-sharing methods. In 2002, Landsbyggefonden, started to guarantee mortgage loans in collaboration with the municipality. In 2013, Landsbyggefonden was authorized to administer and guarantee loans for NHAs without interest rates until 2018. Loans were used as funding for new AH construction done by 25\% rule between 2015 and 2018. In 2018, state began to guarantee and purchase bonds or loans to finance $\mathrm{AH}$ production, while mortgage and commercial banks must pay $0.12 \%$ loan fee to state. These evident changes in AH production lead to the appearance of state control being strengthened, and the authority of local governments to have increased since 1999. However, the decisions made by the state and local governments are highly contingent on the need of financial support from private investors. Mortgage costs of NHAs became higher with state purchasing loan and bond fees paid to mortgage lenders according to new regulation in 2018. Indirectly, these fees can lead to high rents and required deposits for tenants.

The third mechanism is restructuring institutions to open a base for PPPs, which was done in Copenhagen by producing tenure mix housing. Almenbolig+ houses with Emiljhaven project, which were developed with tenure mix through a collaboration among NHA, cooperative and a private housing company. Rent analysis has shown that, the rents of $\mathrm{AH}$ in Copenhagen had $28 \%$ increase 2 years after the financial crisis of 2008. Also, there is a remarkable difference in the rent amount of AH produced in 1940, which has $15 \%$ affordability rate, while housing produced after 2005 is $33 \%$, and $29 \%$ for Almenbolig+ houses for very low-income households in Copenhagen.

In Istanbul, the first mechanism of limiting public finance while increasing authorities of local governments, then encouraging revenue sharing methods was experienced in a faster process than Copenhagen. When state budget for TOKI to finance AH production was abolished in financial crisis of 2001, TOKI was given authority to establish its own budget using revenue sharing methods in 2003. Meanwhile, municipalities were equipped with authority to implement urban renewal projects in 2005, while TOKI was authorized to finance and implement projects if municipalities did not. In 2007, TOKI was given free acquisition of land to be used for urban renewal, by approval of Prime Minister. This led to production of $\mathrm{AH}$ often done on public land in peripheries cross subsidized through funds from revenue sharing with private companies, which were involved with projects implemented in central locations of Istanbul.

State contribution to $\mathrm{AH}$ production for very low-income people is observed in the Istanbul case, similar to Copenhagen. TOKI had financial support from Ministry of Family and Social Policies in 2009 and AH produced for very low-income people with Şile project in 2014. Analysis of income and monthly installments for TOKI houses has shown that affordability rate for very low-income households working in daily jobs is $70 \%$. Also, affordability rate is $32 \%$ for people having social security and formal jobs in Istanbul. An acceptable affordability rate is $30 \%$, and if higher, $\mathrm{AH}$ is a burden for very low-income households. In Copenhagen, the affordability rate for AH produced in the 1940s is $15 \%$ and the rate for housing produced in 2013 is 33\%. Also, AH produced as Almenbolig+ housing 
by PPP has an affordability rate of $29 \%$. This research has shown that $\mathrm{AH}$ is a burden for very low-income households in Istanbul. Similarly, for Copenhagen AH produced after 2005 has an affordability rate of $33 \%$, which is a burden for low income households. However, AH produced between first and second world war period have an affordability rate of $15 \%$ is not a burden for low income people.

OpenAccess This article is distributed under the terms of the Creative Commons Attribution 4.0 International License (http://creativecommons.org/licenses/by/4.0/), which permits unrestricted use, distribution, and reproduction in any medium, provided you give appropriate credit to the original author(s) and the source, provide a link to the Creative Commons license, and indicate if changes were made.

\section{References}

ActNo.221. (2015). Law amending the Law on Planning and the Law on Social Housing (Mixed housing composition) Retrieved from https://www.retsinformation.dk/forms/R0710.aspx?id=168599. Accessed on 13 June 2017.

Background note to the Municipal Plan 2015, 2014-0176948-1 C.F.R. (2015).

Boligkontoret. (2007). Din bolig - dit valg - da beboerne blev herre i eget hus. Retrieved from https://www. bdk.dk/om-boligkontoret-danmark/publikationer/boeger/din-bolig-dit-valg.aspx. Accessed on 08 July 2018.

Brenner, N., \& Theodore, N. (2002). Cities and the geographies of "actually existing neoliberalism". Antipode, 34(3), 349-379.

Bugra, A., \& Candas, A. (2011). Change and continuity under an eclectic social security regime: The case of Turkey. Middle Eastern Studies, 47(3), 515-528.

Coskun, Y. (2015). Türkiye'de Konut Finansmani: Sorunlar ve Çözüm Önerileri. Türkiye Bankalar Birligi, Yayin(310).

Council. (2014). 2014/91 The payment of the price of 75,394.20 TL, which is half of the subsidy price of the residences located in 925 parcels of 2525 islands within the scope of the Sulukule Regeneration Project. 2014/91. Retrieved from http://www.fatih.bel.tr/icerik/9299/2014-yili-temmuz-ayi-meclis-karar -ozetleri/. Accessed on 16 Jan 2017.

De Kam, G., Groetelaers, D., \& Korthals Altes, W. (2008). Land for social housing: A framework for crossnational comparative analysis. Paper presented at the European Network for Housing Research Conference: Shrinking Cities, Sprawling Suburbs, Changing Countrysides.

Denmark, Ministry of Transport. (2017). New agreement on the financing of loans in the general housing sector ensures greater savings. Retrieved from https://www.trm.dk/da/nyheder/2017/ny-aftale-omfinansieringen-af-laan-i-den-almene-boligsektor-sikrer-stoerre-besparelse. Accessed on 05 Sept 2018.

Dodson, J. (2006). Rolling the state?: Government, neoliberalism and housing assistance in four advanced economies. Citeseer: Princeton.

Dorling, D. (2014). All that is solid: How the great housing disaster defines our times, and what we can do about it. London: Penguin.

EcbEurope. (2016). Policy and exchange rates. Retrieved from https://www.ecb.europa.eu/stats/policy_and_ exchange_rates/euro_reference_exchange_rates/html/eurofxref-graph-try.en.html. Accessed on 07 Sept 2018.

Eryıldız, F. G. (2017). Ulusal Ve Yerel Düzeyde Yoksulluk Azaltma Stratejileri: Istanbul'da Sosyal Yardım Uygulamaları. Istanbul: Fen Bilimleri Enstitüsü.

European Commision. (2015). http://ec.europa.eu/eurostat/statistics-explained/index.php/File:Top_30_ global_urban_agglomerations,_2015_(\%C2\%B9)_(millions)_Cities16.png.Accessed on 13 June 2017.

EUROSTAT. (2016). Urban Europe - statistics on cities, towns and suburbs - executive summary (Publication no. ISSN 2443-8219). Retrieved http://ec.europa.eu/eurostat/statistics-explained/index.php/ Urban_Europe_-_statistics_on_cities,_towns_and_suburbs_-_executive_summary. Accessed on 08 July 2017.

Finansministeriet. (2015). Tekst og anmarkninger § 14. Ministeriet for By, Bolig og Landdistrikter. Retrieved from https://www.fm.dk/ /media/publikationer/imported/2015/afl15/14-ministeriet-for-bybolig-og-landdistrikter.ashx?la=da. Accessed on 08 July 2018.

Fox-Rogers, L., \& Murphy, E. (2015). From brown envelopes to community benefits: The co-option of planning gain agreements under deepening neoliberalism. Geoforum, 67, 41-50. 
Galland, D. (2012). Understanding the reorientations and roles of spatial planning: The case of national planning policy in Denmark. European Planning Studies, 20(8), 1359-1392.

Galland, D. (2014). The conversion of spatial planning in Denmark: Changes in national and regional planning policies and governance structures. Treballs de la Societat Catalana de Geografia, 78, 143-162.

GDSA. (2017). Mission of general directorate of social asistance. Retrieved from http://sosyalyardimlar .aile.gov.tr/hakkimizda/sosyal-yardimlar-genel-mudurlugu/sygm-misyon. Accessed on 16 Oct 2017.

Goul Andersen, J. (2011). From the edge of the Abyss to Bonanza-and beyond. Danish economy and economic policies 1980-2011. In L. Mjøset (Ed.), The Nordic varieties of capitalism (pp. 89-165): Emerald Group Publishing Limited.

Günay, Z., Koramaz, T. K., \& Ozuekren, A. S. (2014). From squatter upgrading to large-scale renewal programmes: Housing renewal in Turkey. In R. Turkington \& C.Watson (Eds.), Renewing Europe's housing (Vol. 215-244). Bristol: Bristol University Press.

Hananel, R. (2014). Can centralization, decentralization and welfare go together? The case of Massachusetts affordable housing policy (Ch. 40B). Urban Studies, 51(12), 2487-2502.

Hansen, T. (2007). Dogmebyggeri $i$ det indre Kфbenhavn. Retrieved from http://maleneradhika.com/emalj ehaven/pdf/Byggeplads_dk_2007.pdf. Accessed on 05 Sept 2018.

Jensen, L. (2013). Housing welfare policies in Scandinavia: A comparative perspective on a transition era. LHI Journal of Land, Housing, and Urban Affairs, 4(2), 133-144.

Kab-selvbetjening. (2018a). Almenbolig+. Find housing with KAB in Grøndalsvange and Sundbygård. Retrieved from https://www.kab-selvbetjening.dk/Ansoger/Find-bolig\%23!\%3FgeografiskPla ceringKodeId $=6799 \% 26$ geografiskPlacering2KodeIder $=6806 \% 26$ geografiskPlacering2KodeIder $=6807 \% 26$ geografiskPlacering 2 KodeIder $=6808 \% 26$ geografiskPlacering 2 KodeIder $=6809 \% 26$ geo grafiskPlacering2KodeIder $=6810 \% 26$ geografiskPlacering2KodeIder $=6811 \% 26$ geografiskPlacerin g2KodeIder $=6812 \% 26$ medtagUngdomsboliger $=$ false $\% 26$ medtagAeldreboliger $=$ false $\% 26 \mathrm{medtagFa}$ milieboliger $=$ false $\% 26$ antalLejemaalGrupper $=60 \% 26$ rumMin $=1 \% 26$ rumMax $=2$. Accessed on 16 June 2018.

Kab-selvbetjening. (2018b). Copenhagen northwest housing analysis: Family housing between 80 and 100 square meters. Retrieved from https://www.kab-selvbetjening.dk/Ansoger/Find-bolig $\% 23$ !\%3FgeografiskPlaceringKodeId=6799\%26geografiskPlacering2KodeIder $=6808 \% 26$ arealMin $=80 \% 26$ arealMax $=100 \% 26$ medtagAeldreboliger $=$ false $\% 26$ medtagUngdomsboliger $=$ false $\% 26$ med tagAlmenBoligPlus=false. Accessed on 24 July 2018.

Kab-selvbetjening. (2018c). Copenhagen south housing analysis: Family housing between 80 and 100 square meters. Retrieved from https://www.kab-selvbetjening.dk/Ansoger/Find-bolig\%23!\%3Fgeo grafiskPlaceringKodeId=6799\%26geografiskPlacering2KodeIder $=6809 \% 26$ arealMin $=80 \% 26$ are alMax $=100 \% 26$ medtagAeldreboliger $=$ false $\% 26$ medtag Ungdomsboliger $=$ false $\% 26 \mathrm{medtag} \mathrm{Al}$ menBoligPlus=false. Accessed on 24 July 2018.

kab-selvbetjening.dk. (2018). Boligselskabet AKB, Kфbenhavn Afd: Emaljehaven Område: Kфbenhavn $N V$. Retrieved from https://www.kab-selvbetjening.dk/Ansoger/Find-bolig\%23!\%3FejendomI $\mathrm{d}=1540 \% 23 \% 25253$ FisListeSelected $\% 26$ vejkode $=5240 \% 26 \mathrm{kommunenr}=101$. Accessed on $05 \mathrm{Sept}$ 2018.

Kadi, J., \& Musterd, S. (2015). Housing for the poor in a neo-liberalising just city: Still affordable, but increasingly inaccessible. Tijdschrift voor economische en sociale geografie, 106(3), 246-262.

Karaman, O. (2008). Urban pulse-(re) making space for globalization in Istanbul. Urban Geography, $29(6), 518-525$.

Kommun, K. (2014). Rental Agreement between Copenhagen Municipality and Danish Almene Boliger, the first circle of hits for occupancy of social housing in the period 1. january 2015 -31. december 2018. 2014-014221.

Kommune, K. (2012). Notat Forklade til Boligbarometer2012. Dok nr 2012-476993. Retrieved from https://www.kk.dk/sites/default/files/edoc/fc35a190-c347-4625-89d8-5ed6f9a32987/0dda5 49b-7b79-43e0-a33e-3766a2e4ecb2/Attachments/9657200-9323503-1.PDF. Accessed on 12 Aug 2018.

Kommune, K. (2016). Status på København. Nфgletal for København 2016. Retrieved from Copenhagen: https://www.kk.dk/sites/default/files/Status\%20p\%C3\%A5\%20K\%C3\%B8benhavn\%202016.pdf.

Kommune, K. (2018). STATUS PÅ KØBENHAVN 2018 Opdateret januar 2018. Retrieved from Copenhagen: https://www.kk.dk/sites/default/files/nogletalsrapport_2018_endelig_version_printervenlig. pdf. Accessed on 07 Sept 2017.

Kontanthjælpsloft. (2016). When you receive cash assistance, educational assistance or integration benefits, "Når du modtager kontanthjalp, uddannelseshjalp eller integrationsydelse". Retrieved from Ministry of Empleyment https://www.borger.dk/-/media/borgerdk/Dokumenter/Udbetalingdanma rk/Boligstoette-eksempler-paa-kontanthjaelpsloftpdf.pdf. Accessed on 28 July 2017. 
Kristensen, H. (2002). Social housing policy and the welfare state: A Danish perspective. Urban Studies, $39(2), 255-263$.

Lawno773. (2018). Act amending the Public Housing Act etc. (Financing of public housing with loans granted on the basis of government guaranteed bonds). CX000406. Retrieved from https://www.retsi nformation.dk/forms/R0710.aspx\%3Fid=201759. Accessed on 13 Sept 2018.

LBF. (2013). Deposit, interest-bearing loans. Chapter 4: Payments to the land disposition fund and the newbuilding fund. Retrieved from https://lbf.dk/om-lbf/aarsberetninger/aarsberetning-2015/indbe talinger-til-landsdispositionsfonden-og-nybyggerifonden/indbetaling/\#sectionLink3. Accessed on 23 June 2018.

LBF. (2015). Indbetalinger til landsdispositionsfonden og nybyggerifonden. Annual Report 2015. Retrieved from https://lbf.dk/om-lbf/aarsberetninger/aarsberetning-2015/indbetalinger-til-lands dispositionsfonden-og-nybyggerifonden/lovgivning/. Accessed on 23 June 2018.

LBKnumber269. (2017). Act on Active Social Policy. / Ie / from / 2017/269. Retrieved from https://www. retsinformation.dk/Forms/r0710.aspx\%3Fid=188312\%23idd3150e10-a36f-46be-a3a4-fb851d94b2af. Accessed on 1 July 2018.

LSF135. (2013). Lov om andring af lov om almene boliger m.v. og lov om boligbyggeri. 2013/1. Retrieved from https://www.r2014/91etsinformation.dk/forms/R0710.aspx\%3Fid=161864. Accessed on 21 July 2015.

Mahoney, J. (2000). Path dependence in historical sociology. Theory and Society, 29(4), 507-548.

Marois, T. (2011). Emerging market bank rescues in an era of finance-led neoliberalism: A comparison of Mexico and Turkey. Review of International Political Economy, 18(2), 168-196.

Marsh, A., \& Mullins, D. (1998). The social exclusion perspective and housing studies: Origins, applications and limitations. Housing Studies, 13(6), 749-759.

Mayer, M., \& Kunkel, J. (2012). Introduction: Neoliberal urbanism and its contestations-crossing theoretical boundaries. In J. Kunkel \& M. Margit (Eds.), Neoliberal urbanism and its contestationscrossing theoretical boundaries (p. 225). London: Palgrave Macmillan.

Ministry. (2009). 1096 affordable housing has been given to owners by lottery. Retrieved from http:// www.aile.gov.tr/haberler/ankarada-bin-96-sosyal-konut-kura-ile-sahiplerini-buldu. Accessed on 25 May 2017.

Morel, N., Palier, B., \& Palme, J. (2012). Towards a social investment welfare state?: Ideas, policies and challenges. Bristol: Policy Press.

Nationalbanken. (2017). The central government will buy the bonds to finance social housing in 2018 . Analysis, 25. Retrieved from https:/www.nationalbanken.dk/en/governmentdebt/publications/ Documents/The $\% 20$ central $\% 20$ government $\% 20$ will $\% 20$ buy $\% 20$ the $\% 20$ bonds $\% 20$ to $\% 20$ finance $\% 20$ social\%20housing\%20in\%202018.pdf. Accessed on 23 June 2018.

OECD. (2011). Income distribution and poverty database (report) (publication no. 10.1787). (ISBN 978-92-64-11163-9). Retrieved July 14, 2018, from OECD https://www.oecd.org/els/soc/divid edwestandwhyinequalitykeepsrising.htm.

OECD. (2016). Housing stock and construction. Retrieved September, 10, 2018, from Organisation for Economic Co-operation and Development http://www.oecd.org/social/affordable-housing-database.htm.

OECD. (2017). Income distribution and poverty. Retrieved July 17, 2017, from http://www.oecd.org/social/ income-distribution-database.htm.

OECD. (2018). Income inequality (indicator) (publication no. https://doi.org/10.1787/459aa7f1-en). Retrieved July 14, 2018, from https://data.oecd.org/inequality/income-inequality.htm.

OfficialGazette. (2015). Asgari Ucret Tesbit Komisyon Karari. 2015/1. Retrieved from http://www. resmigazete.gov.tr/main.aspx ?home=http://www.resmigazete.gov.tr/eskiler/2015/12/20151231. htm\&main=http://www.resmigazete.gov.tr/eskiler/2015/12/20151231.htm. Accessed 11 Sept 2018.

Økonomiforvaltningen. (2014). Settlement in Copenhagen "Bosætning i København”. En analyse af bosatningsmфnstre og boligpraferencer, 62. Retrieved from http://forsoegspuljen.almennet.dk/media/56035 2/analyse-af-bosaetning-i-koebenhavn-web.pdf. Accessed on 29 Mar 2018.

Önis, Z. (2006). Varieties and crises of neoliberal globalisation: Argentina, Turkey and the IMF. Third World Quarterly, 27(2), 239-263.

Önis, Z. (2011). Power, Interests and Coalitions: the political economy of mass privatisation in Turkey. Third World Quarterly, 32(4), 707-724.

Palancioglu, H. M., \& Cete, M. (2014). The Turkish way of housing supply and finance for low-and middleincome people. Land Use Policy, 39, 127-134.

Palier, B., \& Hay, C. (2017). The reconfiguration of the welfare state in Europe. Paris: Oxford University Press.

Pickvance, C. G. (2001). Four varieties of comparative analysis. Journal of Housing and the Built Environment, 16(1), 7-28. 
Priemus, H., \& Boelhouwer, P. (1999). Social housing finance in Europe: Trends and opportunities. Urban Studies, 36(4), 633-645.

Rhodes, M. L., \& Mullins, D. (2009). Market concepts, coordination mechanisms and new actors in social housing. European Journal of Housing Policy, 9(2), 107-119. https://doi.org/10.1080/1461671090 2920199.

Scanlon, K., Fernández Arrigoitia, M., \& Whitehead, C. M. (2015). Social housing in Europe. European Policy Analysis, 17, 1-12.

Sellers, J. M., \& Lidström, A. (2007). Decentralization, local government, and the welfare state. Governance, 20(4), 609-632.

4966/4. (2003). The Law of Change on Organization and Duties of Ministry of Public Works and Settlement Law and Change of Some Decisions. Accessed on 17 Sept 2017.

Tillæg44. (2015). Announcement of the municipal on Social Housing. 2015-0218799. Retrieved from https ://www.kk.dk/nyheder/bekendtg\%C3\%B8relse-af-kommuneplantill\%C3\%A6g-om-almene-boliger. Accessed 10 June 2018.

TMB. (2018). Weighted Average Interest Rates For Banks' Loans. Retrieved, from The Central Bank of the Republic of Turkey. http://www.tcmb.gov.tr/wps/wcm/connect/EN/TCMB\%2BEN/Main\%2BMen u/Statistics/Monetary\%2Band\%2BFinancial\%2BStatistics/Interest\%2BStatistics/Weighted\%2BAve rage\%2BInterest\%2BRates\%2BFor\%2BBanks\%2BLoans/. Accessed on 14 July 2018.

TMMOB. (2015). 2016 yili ucretli calisan muhendis, mimar ve sehir plancisi asgari ucreti 21.12.2015. Retrieved from https://www.tmmob.org.tr/icerik/2016-yili-ucretli-calisan-muhendis-mimar-ve-sehir -plancisi-asgari-ucreti-3300-tl-olarak.

TOKI. (2011). Building Turkey of the future, "TOKI Kurum Profili EN". Istanbul: Housing Development Administration (TOKI).

TOKI. (2012). Due diligance document. Ankara: TOKI.

TOKI. (2014). TOKI Konut Uygulamalari 2014. Ankara: Miki Matbaacılık SAN. LTD. ŞTİ.

TOKI. (2016). Corporate profile of TOKI. Ankara: TOKI.

TOKI. (2018a). Illere Göre Projeler. Retrieved September 05, 2018, from https://www.toki.gov.tr/iller e-gore-projeler.

TOKI. (2018b). İstanbul SilivriI 1. VE 2. etap konut uygulamasi satis duyurusu TC Basbakanlik Toplu Konut Idaresi Baskanligi. Retrieved from https://www.toki.gov.tr/AppResources/UserFiles/files/Satis/ Istanbul/Silivri2/ilan.pdf. Accessed on 08 Sept 2018.

Transport, B. o. B. (2018). New agreement on the financing of loans in the general housing sector ensures greater savings. Retrieved from https://www.trm.dk/da/nyheder/2017/ny-aftale-om-finansieringen-aflaan-i-den-almene-boligsektor-sikrer-stoerre-besparelse. Accessed on 05 Sept 2018.

Transport, Danish Ministry of. (2018). Landsbyggefondens $\phi$ konomi. Februar 2018. Retrieved from https ://www.trm.dk/-/media/files/publication/2018/analyse-af-landsbyggefondens-oekonomi-februar-2018. pdf. Accessed on 05 Sept 2018.

Tsenkova, S. (2008). Provision of affordable housing in UNECE countries: Policies and practices. Nairobi: UN-HABITAT.

Tsenkova, S., \& Vestergaard, H. (2011). Social Housing Provision i Copenhagen. Paper presented at the ENHR conference.

TUIK. (2017). Distribution of annual equivalised household disposable income by quintiles ordered by equivalised household disposable income, 2006-2016. Retrieved September 06, 2018, from Turkish Statistical Institute http://www.tuik.gov.tr/PreTablo.do?alt_id=1011.

Turk, S. (2016). The provision of affordable housing by 25\% rule in Copenhagen, Denmark. Paper presented at the Government and Housing in a Time of Crisis: Policy, Planning, Design and Delivery. Liverpool John Moores University, Liverpool.

Turk, S. S., \& Altes, W. K. K. (2010a). Institutional capacities in the land development for housing on greenfield sites in Istanbul. Habitat International, 34(2), 183-195.

Turk, S. S., \& Altes, W. K. K. (2010b). The planning system and land provision for social housing in Turkey. Housing Finance International (Online), 25(1), 26.

Turner, B. (1999). Social housing finance in Sweden. Urban Studies, 36(4), 683-697.

UdbetalingDanmark. (2016). Calculate your housing benefit "Beregn din boligstøtte". Retrieved, from Ministry of Employment https://www.borger.dk/Handlingsside\%3FselfserviceId=a153fd97-6252-4058ac3f-5a59079cbded. Accessed on 28 July 2017.

URL-1. (2016). Asgari Ucret Tespit Komisyon Karari. Tarih/Sayl: 20151231.043. Retrieved from http:// www.maligundem.com/gundem/haberdetay.asp?ID=727. Accessed on 07 Sept 2018.

URL-2. (2013). 199 homeowners of Sulukule Urban Renewal Project has been granted with 4.474.887,00 TL from municipal budget. Retrieved from http://www.fatihhaber.com/fatihhaber/suluklule10mily on.htm. Accessed on 20 Dec 2016. 
URL-3 (Producer). (2018). Toki Şile 3. Etap 'ta 112 konut yapacak (2018). Toki Şile 3. Etap daire fiyatları. Retrieved from http://evdenhaberler.com/toki-sile-3-etap-ta-112-konut-yapacak-2018/.

Velfærdsministeriet. (2009). Den almene boligsektors finansiering, second report of the committee on future governance of the general housing sector. Retrieved from Copenhagen: http://www.ft.dk/samli ng/20081/almdel/bou/bilag/71/658881.pdf.

Publisher's Note Springer Nature remains neutral with regard to jurisdictional claims in published maps and institutional affiliations. 